\section{Banging the Freedom drum}

\section{Washington}

National Aeronautics and Space Administration (NASA) officials like to say that no matter what objectives are chosen by the United States for space activities in the twenty-first century, "all roads begin with the space station Freedom". But as NASA pleads its case before a budget-conscious Congress, Freedom's \$16,800-million price tag practically guarantees that its own road into space will be a rocky one.

Now set to be deployed in the mid1990 s, the space-station programme is building momentum. Last September, Canada and the European Space Agency signed formal participation agreements (see Nature 335, 480; 1988), and earlier this month Japan signed a memorandum of understanding. Altogether, NASA's foreign partners will contribute $\$ 8,000$ million to the project.

President George Bush is an enthusiastic proponent of the space station. Nervous about the cost, Congress last year appropriated $\$ 900$ million for the space station, but ordered $\$ 515$ million to be held back until 15 May this year so the new president could decide whether to proceed. President Bush has already indicated that the money will be released for the space station.

This year, NASA is requesting $\$ 2,050$ million for its space-station activities. Three-quarters of that money will go to the four aerospace companies with which NASA signed contracts last September to build major elements of the station. Boeing is developing the crew living quarters and logistic elements; McDonnell Douglas is pursuing the central truss structure and resource nodes; General Electric is developing the polar platform and attached payload accommodations on the main station; and Rocketdyne is developing the power systems.

For its part, Congress is enthusiastic about the idea of the space station, but budgetary concerns make any new and expensive project vulnerable. The word around Congress is that as much as $\$ 1,000$ million may be cut from NASA's total 1990 budget request of $\$ 13,300$ million, and some of that is bound to come from the space station.

But space-station officials are already feeling pinched, and have warned that further cuts could be devastating. NASA has not been able to find funds for nearly a third of the 2,644 posts authorized for the programme. At a hearing on 16 March before the Senate Commerce, Science and Transportation Subcommittee on Science, Technology and Space, NASA Associate Administrator for the Office of Space Station James Odom testified that "virtually any cut would do major hurt, and a significant cut would be tantamount to killing the programme". Odom also warned that backing out on NASA's commitments to its foreign partners would also have devastating effects.

Launching the space station is planned to take 20 space-shuttle flights, the first of which is now scheduled for 1995. Human occupancy should be possible after the fourth shuttle flight, and a permanent crew can stay on board after flight 13 .

The space station's attached science payloads - now likely to include a gamma-ray/cosmic-ray focusing device called Astromag and a cosmic dust sampler - are intended for flight 7 , an early

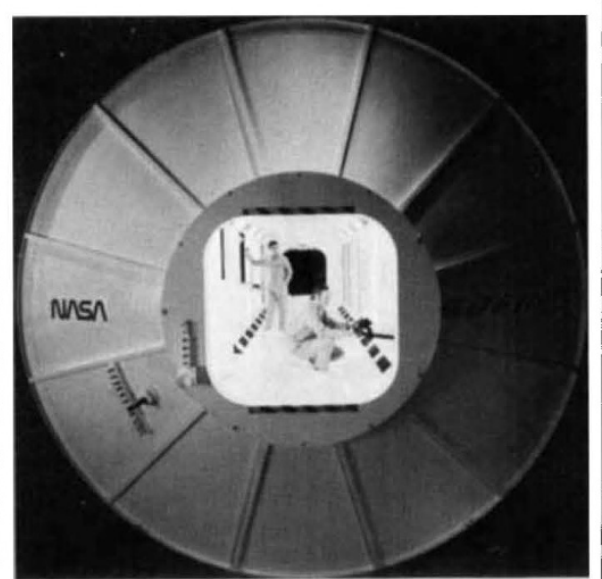

Installing equipment in Boeing's mock-up of Freedom's living quarters.

flight that supporters say is indicative of NASA's commitment to doing science on board the space station. The launch schedule for the flights is based on current shuttle lift capabilities, and a new advanced solid rocket motor, once it becomes available, could speed up the process.

A decision to move forward with shuttle-C, a cargo-only version of the shuttle devised as an alternative option, would also be a boon for the space station, but so far the administration has shown little support for this plan.

Coordinating the development of hardware with that of scientific instruments so that both will be ready to fly on time will be a tricky business. As an example, General Electric has already begin work on the polar platform, but funding for the platform instruments, which have already been selected, will not be formally requested until the 1991 fiscal year. Lastminute modifications to spacecraft hardware to accommodate instruments can be extremely expensive, and can cause delays.

Although NASA has agreed with the

\section{On-again, off-again Landsats on again Washington}

LANDSATS 4 and 5 are back in business for the moment. The Earth Observation Satellite Company (EOSAT) announced on 15 March that the shut down order issued by the National Oceanic and Atmospheric Administration (NOAA) had been rescinded.

EOSAT, which operates the two Earth remote sensing satellites for NOAA, had begun shut down procedures that would have terminated Landsat operations at the end of the month (see Nature 338, 194; 16 March 1989).

Details of the financial rescue package have not been revealed, but EOSAT says it costs $\$ 9.4$ million to operate the two Landsat spacecraft. NOAA officials will only say that the reprieve will last at least until the Bush Administration completes a review of the programme now under way.

The rescue effort was coordinated by the new National Space Council chaired by Vice-President Dan Quayle. Members of Congress have reported that their offices have been inundated by letters asking that money be spent to keep the Landsats alive.

Joseph Palca

White House Office of Management and Budget to cap spending on the space station at $\$ 16,800$ million, several elements of the station, such as operations costs, facilities, launch costs, communications support and several new features including an emergency crew escape vehicle, are not covered by the cap. Other programmes at NASA have been cut back in order to provide adequate money for necessary space-station development and activities.

There has long been tension between space scientists and those favouring manned space activities. Station chief scientist John Bartoe acknowledges that selling the station solely as a tool for science is untenable, but that it can useful for scientists once they learn its capabilities. It seems likely that the successor to James Fletcher, who has announced his resignation as NASA administrator, will continue the strong support NASA has traditionally provided to the manned space programme.

Proponents of the space station are trying to secure the high ground in their efforts on behalf of the space station. At the Senate hearing earlier this month, Senator Al Gore (Democrat, Tennessee) set the tone for the coming Congressional debate that will make opponents of the space station squirm: "The choice facing us this year is not just between moving ahead with the space station or not, but between continues leadership in space and abdication and decline."

Joseph Palca 